\title{
EFFECT OF USING NATURAL FEED ADDITIVES ON PERFORMANCE OF DAIRY FRIESIAN COWS
}

\author{
A.M.M. Zeid, A.M.A. Mohi-Eldin, I.M.E. Shakweer, Ebtehag, I.M. \\ Abouelenin and Fathia A. Ibrahim \\ Animal Production Research Institute, Agricultural Research Center, Dokki, Giza, \\ Egypt
}

\section{SUMMARY}

Twenty eight lactating Friesian cows averaged $520 \mathrm{~kg}$ live body weight were assign to evaluate the effect of supplementation of lactating Friesian cows with yeast culture and Enzyme on milk production efficiency. Cows were divided into four experimental groups and fed the same basal ration but differed in feed additives. Cows in the $1^{\text {st }}$ group (T1) were fed a basal ration containing concentrate feed mixture, berseem hay, rice straw and corn silage (control). Cows in the $2^{\text {nd }}(T 2)$ and $3^{\text {rd }}$ (T3) were fed the basal ration supplemented with $10 \mathrm{~g}$ enzyme(Fibrozyme containing $100 \mathrm{XU} / \mathrm{g}$ xylanase) and $10 \mathrm{~g}$ yeast culture (Yea-Sacc containing $10^{8}$ cells of Saccharomyces cerevesiae/g), respectively. While, those in the $4^{\text {th }}$ group (T4) were fed the basal ration supplemented with $5 g$ yeast $+5 g$ Enzyme. Feeding period lasted for 16 weeks. Four digestibility trials using 12 lactating Friesian cows, three in each trial were conducted to determine nutrient digestibility coefficients and feeding values in experimental groups. Rumen and blood parameters, feed utilization and economic efficiency were also studied. Results showed that cows fed rations supplemented with both $10 \mathrm{~g}$ yeast, $10 \mathrm{~g}$ Enzyme and $5 \mathrm{~g}$ yeast plus $5 \mathrm{~g}$ Enzyme improved $(P<0.05)$ most nutrient digestabilities and feeding values as TDN and DCP compared with control ration, as well as rumen and blood parameters. Milk yield as actual milk yield and 4\% fat corrected milk, total yields of fat and protein in milk and economic efficiency were the highest $(P<0.05)$ for cows in T4 and T3.

In the light of the present results cows with yeast culture, mixture yeast plus enzyme and enzyme tended to have greater beneficial effects in the performance and had improved the economic efficiency of milk production, especially those treated with $10 \mathrm{~g}$ yeast $/ \mathrm{h} / \mathrm{d}$.

Keywords: Friesian cows, yeast culture, Enzyme, digestibility, milk yield, blood

\section{INTRODUCTION}

An enzyme is a naturally occurring protein that catalyzes chemical reactions in biological systems. Enzymes promote the breakdown of complex feed molecules into smaller chemical fractions such as glucose or amino acids that are digestible by the ruminant animal. An example, the enzyme cellulase initiates the breakdown of cellulose (fiber) into sugars. Common enzyme additives contain cellulases, hemicellulases, xylanases, amylases, and pectinases. Cellulases, hemicellulases, and pectinases are enzymes that degrade the fiber portion of forages. Amylase breaks

Issued by The Egyptian Society of Animal Production 
down starch (amylose) therefore its use would be directed towards starch containing silages such as corn silage.

Research data also suggests that hemicellulases and pectinases are more effective than cellulases at reducing fiber content. Unfortunately,hemicellulases and pectinases break down fiberfractions (hemicellulose, pectin) that are more easily digested by ruminants. Consequently, these enzymes reduce the concentration of digestible NDF fractionsrather than the indigestible NDF fraction cellulose. Interestingly, current trends in enzyme technology involve incorporating enzymes directly into total mixed rations (TMR's) or silages prior to feeding. Initial research has observed some positive effects using this method. The economics of this practice have yet to be determined.

Fungal supplements (Aspergillus oryzae and Saccharomycescerevisiae) have improved DMI, milk production, milk composition, and Body weight gain of dairy cows (Besong et al. (1993), Dawson, et al. (1990), Fuller (1989) and Piva,et al. (1993)). Improvements in performance have been attributed to increased numbers of ruminalcellulolytic bacteria, improvements in ruminal fiber degradation, and changes in ruminal VFA (Arambel et al. (1987), Martin and Nisbet (1990) and Wiedmeier, (1987)). Yeast may also provide growth factors, such as malate, to bacteria that utilize lactate that in turn maymoderate changes in ruminal $\mathrm{pH}$ (Nisbet, and Martin. 1991). Yeast cultures also have been shown to stimulate utilization of hydrogen by ruminal acetogenic bacteria Chaucheyras, et al. (1995). However, supplemental yeast has not always altered ruminal metabolism (Adams et al., 1981), Judkins and Stobart (1988) and Kim et al. (1993) or improved animal performance (Harris et al., 1992) and Swartz et al. (1994).

Yeast cultures prepared from active cultures of Saccharomyces cerevisiae have been used in animal feeds for over six decades. The response to yeast cultures by lactating dairy cows has been variable.In some studies, yeast cultures have improved DMI (Fallon and Harte. 1987), Malcolm and Kiesling. (1986) and Williams et al. (1991), milk yield (Kellems, et al. (1990), Piva et al. (1993), Williams et al. (1991) and Wohlt et al. (1991)), and milk composition (Williams et al. (1991) and Wohlt et al. (1991); other studies, (Arambel and Kent, 1990, Erdman and Sharma, 1989 and Quinonez et al. (1988) found no response to yeast cultures. Piva et al. (1993) suggested that several factors, including stage of lactation, type of forage fed, feeding strategy, and forage to concentrate ratio, are likely to affect the response to yeast cultures in dairy cows. Kellems et al. (1990) reported that microbial additives such as yeast cultures had the greatest effect on cowsin early lactation, increasing milk yield over that of control cows. Williams et al. (1991) found that yeast cultures had the greatest effect when diets contained $60 \%$ concentrate and $40 \%$ forage.

The objective of these experiment was to determine the effects of a live yeast and enzyme supplement on some rumen and blood parameters and on the performance of lactating cows.

\section{MATERIALS AND METHODS}

The presented study was conducted at Dina Farm (Cairo-Alexandria desert rode km.86). Twenty eight lactating Friesian Cows ( in $3^{\text {rd }}-5^{\text {th }}$ lactating season ) were taken one week post- partum and were randomly distributed according to lactation season and milk yield into four similar groups ( 7 animal each ) to evaluate the effect 
of feeding concentrate feed mixture, berseem hay, rice straw and corn silage with or without enzyme (Fibrozyme containing 100XU/g xylanase), yeast (Yea-Sacc containing $10^{8}$ cells of Saccharomyces cerevesiae/g) and mixture from enzyme plus yeast on animal performance .

\section{Experimental rations:}

Animal in all groups were fed according to NRC (1989) as follows: The first group was fed concentrate feed mixture (CFM), berseem hay (BH), corn silage (CS) and rice straw (RS) and was considered as a control (T1). Cows in the $2^{\text {nd }}$ group were fed control ration plus $10 \mathrm{~g}$ enzyme (T2), $3^{\text {rd }}$ group were fed control ration plus $10 \mathrm{~g}$ yeast (T3) and $4^{\text {th }}$ group were fed control ration plus 5 g. enzyme +5 g. yeast (T4) .

\section{Cows and feeding :}

Cows were fed individually twice daily at 8.00 a.m. and 4.00 p.m. All daily feed residuals were recorded and so daily feed consumption were determined .

Cows were milked twice daily at 7.00 a.m. and 5.00 p.m. Daily milk yields were individually recorded during the experimental period. Actual milk yield was corrected to $4 \%$ FCM according to the formula of Gaines (1923). Samples of milk were collected weekly at the morning and the evening milking . Composite milk samples ( relative to the quantity of milk production ) were taken and frozen for chemical analysis. Milk analysis was determined by milko Scan . Total nitrogen content (TN) was determined using semi-micro Kjeldahl method, meanwhile total solids (TS) and ash contents were measured according to Ling (1963).

\section{Digestibilty trial :}

At the end of the feeding experimental that lasted 90 days, three cows were randomly chosen from each group to evaluate the feeding values of experimental rations. Grab sample method and silica as internal marker were applied for the digestibility determination according to Van Keulen and young (1977). Feces samples were collected twice daily at $12.00 \mathrm{hrs}$. intervals for three successive days from each cow. Solution of $10 \% \mathrm{H}_{2} \mathrm{So}_{4}$ was added to the representative samples before drying in oven at $60{ }^{\circ} \mathrm{C}$ for $24.00 \mathrm{hrs}$. Dried samples were ground and kept for chemical analysis according to A.O.A.C. (1995) .

\section{Rumen liquor samples :}

At the end of each digestibility trial, rumen liquor samples were collected from three cows of each group by stomach tube at $4.00 \mathrm{hrs}$ post morning feeding. Samples were directly strained through four folds of gauze and divided into two portion. One for the immediately estimation of $\mathrm{pH}$ and ammonia nitrogen $\left(\mathrm{NH}_{3}-\mathrm{N}\right)$ while the other was stored in the deep freezer after added toluene and paraffin oil for total volatile fatty acid concentration (TVFA's ) determination. Samples were tested for $\mathrm{pH}$ value digital $\mathrm{pH}$ meter. Ammonia-N concentration was determined according to Conway (1957). TVFA's was determined according to Warner,(1964).

\section{Blood serum constituents :}

One blood samples were collected from the jugular vein of three animal from each group at the end of feeding trial. The collected blood samples were centrifuged 
at 4000 r.p.m for 20 min. . Blood serum was tested for total protein , albumin, GOT, GPT and creatinin using commercial kits.

The chemical composition of the feedstuffs are illustrated in Table (1). Chemical analysis using methods of A. O. A. C. (1995) was performed on representative samples from all experimental feedstuffs.

Efficiency of feed utilization was calculated as the amount of $4 \%$ FCM produced by $1 \mathrm{~kg}$ DM, TDN and DCP consumed. The economical efficiency for milk production expressed as the ratio between the price of milk produced and the cost of feeds consumed was estimated on the basis of the following price in Egyptian pounds per kg. for milk, LE. 1.78, concentrate feed mixture LE. 1244, berseem hay LE. 500, corn silage LE. 150, rice straw LE. 75, yeast LE. 35 and Enzyme LE. 60.

Statistical analysis was carried out using general linear procedure of SAS user's guide, (1996) .Group mean differences were tested using least significant differences (Duncan, 1955).

Table 1. Chemical composition of the ingredients

\begin{tabular}{lccccccc}
\hline \multirow{2}{*}{ Items } & \multicolumn{7}{c}{ Composition on DM\% bases } \\
\cline { 2 - 8 } & DM & OM & CP & EE & CF & NFE & Ash \\
\hline *Concentrate feed mixture & 91.61 & 92.59 & 16.8 & 3.1 & 12.4 & 60.29 & 7.41 \\
Berseem hay & 93.98 & 87.2 & 14.42 & 2.75 & 23.62 & 46.41 & 12.8 \\
Corn silage & 34.9 & 92.37 & 9.4 & 2.5 & 24.88 & 55.59 & 7.63 \\
Rice straw & 93.33 & 84.6 & 3 & 1.87 & 34.91 & 44.82 & 15.4 \\
\hline *Concentrate feed mixture consists of : 25\% yellow maize, 27\% undecorticated cotton seed meal, 20\% \\
rice bran, 15\% wheat bran, 5\%soybean meal, 5\% molasses, 2\% limestone, 1\% common salt.
\end{tabular}

\section{RESULTS AND DISCUSSION}

\section{Nutrient digestibility and Nutritive values:}

Data in Table (2) indicate that supplementation of yeast culture and enzyme in rations in the T2, T3 and T4 resp. showed the significantly effect on digestibility of $\mathrm{DM}, \mathrm{OM}, \mathrm{CP}, \mathrm{CF}$ and NFE compared with control $(\mathrm{P}<0.05)$ in $\mathrm{EE}$ there is no significantly difference between control and other treatments. This results agreement with those reported by Harrison, et al. (1988). Wohlt et al. (1998) found that CP digestibility tended to be improved by cows fed a diet supplemented with yeast culture.

On the other hand, Mohi-Eldin et al. (2008) indicated that the supplementation of different yeast culture in calf's ration did not any effect on DM, OM, EE and CP digestibility .

The nutritive value as TDN\% and DCP\% in Table (2) showed that TDN\% ranged between 60.44 and $66.36 \%$, the lowest value was recorded for T1 (control), while, T3, T4 and T2 rations had the higher values. The differences were significant among treatments. This results are in agreement with Ibrahim et al. (2006) and Mohi-Eldin, et al. (2008).

The DCP values in Table $(2)$ were significant $(\mathrm{P}<0.05)$ increased for supplementation with yeast culture and enzyme compared to control ration. 
On other hand, Ibrahim et al., (2006) found that the yeast culture additive into lamb ration had no significant effect on the nutritive values estimated as TDN and DCP.

Table 2. Digestion coefficients and nutritive value of experimental rations (on DM basis)

\begin{tabular}{lcccc}
\hline & \multicolumn{4}{c}{ Experimental rations } \\
\cline { 2 - 5 } Items & T1 & T2 & T3 & T4 \\
\hline Digestibility coefficients \% & & & & \\
DM & $62.55^{\mathrm{b}}$ & $66.67^{\mathrm{a}}$ & $66.56^{\mathrm{a}}$ & $66.58^{\mathrm{a}}$ \\
OM & $64.14^{\mathrm{c}}$ & $67.92^{\mathrm{b}}$ & $70.16^{\mathrm{a}}$ & $69.74^{\mathrm{ab}}$ \\
CP & $66.13^{\mathrm{b}}$ & $74.32^{\mathrm{a}}$ & $73.76^{\mathrm{a}}$ & $72.70^{\mathrm{a}}$ \\
EE & $69.92^{\mathrm{a}}$ & $71.43^{\mathrm{a}}$ & $72.81^{\mathrm{a}}$ & $72.09^{\mathrm{a}}$ \\
CF & $64.69^{\mathrm{b}}$ & $70.21^{\mathrm{a}}$ & $69.18^{\mathrm{a}}$ & $69.70^{\mathrm{a}}$ \\
NFE & $63.18^{\mathrm{b}}$ & $65.37^{\mathrm{b}}$ & $69.54^{\mathrm{a}}$ & $68.94^{\mathrm{a}}$ \\
Nutritive values & & & & \\
TDN & $60.44^{\mathrm{c}}$ & $64.25^{\mathrm{b}}$ & $66.36^{\mathrm{a}}$ & $66.01^{\mathrm{ab}}$ \\
DCP & $8.17^{\mathrm{b}}$ & $9.37^{\mathrm{a}}$ & $9.46^{\mathrm{a}}$ & $9.28^{\mathrm{b}}$ \\
\hline
\end{tabular}

$\mathrm{a}, \mathrm{b}$ and $\mathrm{c}$ : Means followed by different letters in the same row are significantly different $(\mathrm{P}<0.05)$

\section{Ruminal Activity}

The parameters rumen liquers for group animals fed different with Enzyme resulted in significantly $(\mathrm{P}<0.05)$ higher in $\mathrm{pH}$ value while supplemented ration with yeast culture did not significantly affect . Morever, the animals fed tested rations (T2, $\mathrm{T} 3$ and T4) appeared to lower significant in NH3-N concentration compared to those of fed control ration. However, the significant $(\mathrm{P}<0.05)$ differences between $\mathrm{T} 2$ and T3 were found (Table 3 ). The variation in NH3-N concentration among different treatment might be attributed to reduced ammonia- $\mathrm{N}$ absorption by rumen epithelium or increase/ decrease efficiency of microbial protein Synthesis (Smith et al., 1980). The higher concentration of NH3-N might be due to the degradation of protein and hydrolysis of NPN substances (Reddy et al., 1989). Results revealed that the significant increase of ruminal VFA's concentration were recorded with animals feed tested ration, being $15.00,15.65$ and $15.50 \mathrm{meq} / 100 \mathrm{ml}$ for T2, T3 and T4 , respectively. So ration supplemented with enzyme or/ and yeast culthur tended to have get higher VFA's concentration.

\section{Blood parameters:}

Results obtained in Table (3) indicated that animal groups fed supplemented rations $(\mathrm{T} 2, \mathrm{~T} 3$ and $\mathrm{T} 4)$ had a significantly $(\mathrm{P}<0.05)$ higher concentration of serum protein fraction such as total protein, Albumen and globulin compared with those fed control ration. Higher significant differences in serum protein fraction concentration might be attributed to synthesis liver function and higher digestibility of $\mathrm{CP}$ and $\mathrm{OM}$ of tested rations, which indicated better utilization of dietary protein owing to supplemented rations with feed additives. These results were agreement with those reported by Abd ElKhalek et al. (2000). They found that serum albumin 
concentration was significantly higher with rate of $6.5 \%$ in calves fed supplemented ration with yeast. However, total protein in this study was within the normal range. On the other hand, all values of serum urea-N and creatinin concentrations were significantly $(\mathrm{P}<0.05)$ lower with supplemented rations $(\mathrm{T} 2, \mathrm{~T} 3$ and $\mathrm{T} 4)$ compared to the control ration (T1). Concentration of serum urea-N and creatinin might be attributed to efficiency of $\mathrm{N}$ utilization in ruminat (Lewis et al., 1957). The results were agreement with those reported by Fayed (1995). In general, from these results, it could be noticed that the supplemented rations with either enzymes or yeast culture as feed additives tended to significantly $(\mathrm{P}<0.05)$ affected in some blood parameters.

Table 3. Some rumen liquer and blood parameters of lactating cows fed on experimental rations

\begin{tabular}{lcccc}
\hline & \multicolumn{4}{c}{ Experimental rations } \\
\cline { 2 - 5 } Items & T1 & T2 & T3 & T4 \\
\hline Rumen liquer: & $6.25^{\mathrm{b}}$ & $6.40^{\mathrm{a}}$ & $6.22^{\mathrm{b}}$ & $6.31^{\mathrm{ab}}$ \\
pH & $24.92^{\mathrm{a}}$ & $22.92^{\mathrm{b}}$ & $21.47^{\mathrm{c}}$ & $22.08^{\mathrm{c}}$ \\
NH3-N mg/100ml & $12.36^{\mathrm{b}}$ & $15.00^{\mathrm{a}}$ & $15.65^{\mathrm{a}}$ & $15.50^{\mathrm{a}}$ \\
TVFA's meq./100ml & & & & \\
Blood parameters: & $6.86^{\mathrm{b}}$ & $7.55^{\mathrm{a}}$ & $7.49^{\mathrm{a}}$ & $7.51^{\mathrm{a}}$ \\
Total protein g/100ml & $3.65^{\mathrm{b}}$ & $4.23^{\mathrm{a}}$ & $4.04^{\mathrm{a}}$ & $4.14^{\mathrm{a}}$ \\
Albumen g/100ml & $3.21^{\mathrm{a}}$ & $3.32^{\mathrm{a}}$ & $3.45^{\mathrm{a}}$ & $3.37^{\mathrm{a}}$ \\
Glubulin $\mathbf{g} / \mathbf{1 0 0 m l}$ & $26.60^{\mathrm{a}}$ & $24.56^{\mathrm{b}}$ & $24.40^{\mathrm{b}}$ & $24.45^{\mathrm{b}}$ \\
Urea-N mg/100ml & $1.59^{\mathrm{a}}$ & $1.39^{\mathrm{b}}$ & $1.33^{\mathrm{b}}$ & $1.34^{\mathrm{b}}$ \\
Creatinin & $38.02^{\mathrm{a}}$ & $36.65^{\mathrm{b}}$ & $36.89^{\mathrm{b}}$ & $36.75^{\mathrm{b}}$ \\
GOT IU/L & $24.12^{\mathrm{a}}$ & $23.61^{\mathrm{a}}$ & $23.71^{\mathrm{a}}$ & $23.64^{\mathrm{a}}$ \\
GPT IU/L & & & & \\
\hline
\end{tabular}

$\mathrm{a}, \mathrm{b}$ and $\mathrm{c}$ : Means followed by different letters in the same row are significantly different $(\mathrm{P}<0.05)$

\section{Milk Production, its composition and feed utilization efficiency:}

The average daily milk and 4\% FCM yield are presented in Table (4). It could be noticed that both milk yield and 4\% FCM were significantly $(\mathrm{P}<0.05)$ increased with different treatments (T2, T3 and T4) compared to control (T1).

Cows received rations supplements with both enzyme and yeast (T4) recorded the highest value of daily 4\% FCM $(15.22 \mathrm{~kg})$, followed by those supplemented with yeast culture $(15.05 \mathrm{~kg})$ and those supplemented with enzyme $(14.63 \mathrm{~kg})$. Results obtained revealed that the daily 4\% FCM yield were improved and increased by 15.74, 19.07 and $20.41 \%$ for animals fed rations supplemented with enzyme (T2), yeast culture (T3) and enzyme plus yeast culture (T4), respectively. These results were agreement with those reported by Besong et al. (1993), Dawson, et al. (1990), Fuller (1989) and Piva, (1993) who found that enzyme and yeast additives enhanced milk production in lactating cows .

The improvements in performance of cows might be attributed to increase numbers of ruminal celluloytic bacteria, improvements in ruminal fiber degradation 
and changes in ruminal VFA according to Arambel et al. (1987), Martin and Nisbet (1990) and Wiedmeier (1987).

In addition, the fat, protein, lactose, total solids and solids not-fat of milk were influenced significantly $(\mathrm{p}>0.05)$ by yeast or enzyme addition. This improvement in milk composition may be due to the range of effects in rumen, including in $\mathrm{pH}$, altered VFA concentrations, decreased methane production, increased number of cellulolytic bacteria and increased rate and extend of rumen fiber digestion (Dawson and Newman (1987), Harrison, et al. (1988), Wiedmeier, et al. (1987) and Williams, et al. (1991).

Table 4. Total intak, average daily milk yield and its composition and feed utilization efficiency of lactating cows

\begin{tabular}{lcccc} 
& & Experimental rations & \\
\cline { 3 - 4 } Items & T1 & T2 & T3 & T4 \\
\hline Daily total intake, kg & & & & \\
DM & $15.13^{\mathrm{b}}$ & $15.54^{\mathrm{a}}$ & $15.74^{\mathrm{a}}$ & $15.60^{\mathrm{a}}$ \\
TDN & $9.14^{\mathrm{c}}$ & $9.98^{\mathrm{b}}$ & $10.45^{\mathrm{a}}$ & $10.30^{\mathrm{a}}$ \\
DCP & $1.24^{\mathrm{c}}$ & $1.46^{\mathrm{ab}}$ & $1.49^{\mathrm{a}}$ & $1.45^{\mathrm{b}}$ \\
Daily milk yield, kg & $13.94^{\mathrm{b}}$ & $16.13^{\mathrm{a}}$ & $16.58^{\mathrm{a}}$ & $16.35^{\mathrm{a}}$ \\
Daily 4\% FCM,kg & $12.64^{\mathrm{b}}$ & $14.63^{\mathrm{a}}$ & $15.05^{\mathrm{a}}$ & $15.22^{\mathrm{a}}$ \\
Milk composition,\% & & & & \\
Milk fat & $3.38^{\mathrm{c}}$ & $3.52^{\mathrm{b}}$ & $3.68^{\mathrm{a}}$ & $3.62^{\mathrm{a}}$ \\
Milk protein & $3.24^{\mathrm{b}}$ & $3.41^{\mathrm{a}}$ & $3.44^{\mathrm{a}}$ & $3.4^{\mathrm{a}}$ \\
Milk lactose & $4.45^{\mathrm{b}}$ & $4.84^{\mathrm{a}}$ & $4.89^{\mathrm{a}}$ & $4.82^{\mathrm{a}}$ \\
Milk T.S. & $11.08^{\mathrm{d}}$ & $11.68^{\mathrm{c}}$ & $12.02^{\mathrm{a}}$ & $11.84^{\mathrm{b}}$ \\
Milk S.N.F. & $7.70^{\mathrm{d}}$ & $8.15^{\mathrm{c}}$ & $8.34^{\mathrm{a}}$ & $8.22^{\mathrm{b}}$ \\
4\% FCM production efficiency & & & & \\
FCM kg/kg DM & 0.835 & 0.941 & 0.956 & 0.975 \\
FCM kg/kg TDN & 1.383 & 1.466 & 1.440 & 1.477 \\
FCM kg/kg DCP & 10.19 & 10.02 & 10.10 & 10.50 \\
\hline
\end{tabular}

$\mathrm{a}, \mathrm{b}, \mathrm{c}$ and $\mathrm{d}$ : Means followed by different letters in the same row are significantly different $(\mathrm{P}<0.05)$

Feed conversion and production efficiency:

Data presented in Table (4) showed that the production efficiency expressed as $\mathrm{kg}$ $4 \% \mathrm{FCM} / \mathrm{kg} \mathrm{DM}$, TDN or DCP for cows fed supplemented ration with enzyme and yeast culture (T4) were $0.975,1.477$ and $10.50 \mathrm{~kg}$, respectively .

Improvement in production efficiency as $\mathrm{kg} 4 \% \mathrm{FCM} / \mathrm{kg}$ TDN ranged between 4.12-6.80\%. From these data, it could be concluded that cows fed supplemented ration with enzyme or/and yeast culture appeared to improve production efficiency and feed conversion with no adverse effects.

Economic efficiency:

Concerning the feed cost, results in Table (5) revealed that the feed cost /head/day was $0.905,0.850,0.832$ and $0.787 \mathrm{LE}$. With cows fed T1,T2, T3 and T4, respectively 
showing the highest economic with T4. Average daily feed cost/head was reduced as aresults to supplement of ration with feed additives such as enzyme or/ and yeast culture. So, the highest economical efficiency was related to the lowest feed cost and highest 4\% FCM yield which appeared with cows fed rations supplemented with enzyme plus yeast culture (T4).

Table 5. Economic efficiency of lactating cows

\begin{tabular}{lcccc}
\hline Items & \multicolumn{4}{c}{ Experimental rations } \\
\cline { 2 - 5 } & T1 & T2 & T3 & T4 \\
\hline Input costs (LE) & 11.44 & 12.44 & 12.52 & 12.55 \\
output (LE) & 22.50 & 26.04 & 27.59 & 28.39 \\
Economic efficiency & 1.97 & 2.09 & 2.20 & 2.26 \\
Feed cost/kg 4\% FCM (LE) & 0.905 & 0.85 & 0.832 & 0.787 \\
Milk production as \% of the control group & - & & & \\
Actual milk yield & 100 & 115.71 & 118.94 & 117.29 \\
$\mathbf{4 \% F C M}$ & 100 & 115.74 & 119.07 & 120.41 \\
\hline
\end{tabular}

\section{CONCLUSION}

Cows fed ration supplemented with feed additives such as enzyme or/and yeast culture tended to increase in nutrient digestibility, nutritive value, with no adverse effects on rumen and blood serum parameters. Moreover, these supplementation showed increase in milk yield and economical efficiency.

\section{REFERENCES}

A.O.A.C., 1995. Official methods of analysis $15^{\text {th }}$ ed. Association of Official Analytical Chemists. Washington, Virginiall U.S.A.

Abdel-Khalek , A.E; A.F.Mehrz and E.A.Omar, 2000. Effect of yeast culture (LactoSacc) in rumen activity, blood constituents and grow of suckling Friesian calves. Proceeding of the Conf. on animal production in the $21^{\text {st }}$ centry, Sakha Kafr- EL Sheikh, 18-20 April 2001.

Adams, D.C., M.L. Galyean, H. E. Kiesling, J.D. Wallace and M.D. Finkner, 1981. Influence of viable yeast culture, sodium bicarbonate, and monensin on liquid dilution rate, rumen fermentation, and feedlot performance of growing steers and digestibility in lambs. J. Anim. Sci. 53:780.

Arambel, M.J. and B.A. Kent, 1990. Effect of yeast culture on nutrient digestibility and milk yield response in early to midlactation dairy cows. J. Dairy Sci. 73:1560-1563.

Arambel, M. J., R. D. Weidmeier and J.L. Walters, 1987. Influence of donor animal adaptation to added yeast culture and (or) Aspergillus oryzae fermentation extract. Nutr. Rep. Int. 35:433.

Besong, S., R.W. Hemken, and J.A. Jackson, 1993. Influence of dietary yeast product on DMI, milk yield, milk flavor, and ruminal composition in lactating dairy cows. J. Dairy Sci. 76 (Suppl. 1):204 (Abstr.)

Chaucheyras, F., G. Fonty, G. Bertin, and P. Gouet, 1995. In vitro H2 utilization by a ruminal acetogenic bacterium cultivated alone or in association with an archea 
methanogen is stimulated by a probiotic strain of Saccharomyces cerevisiae. Appl. Environ. Microbiol. 61:3466.

Conway, E. J., 1957. Microdiffusion analysis In: Association of Official Analysis

Dawson, K. A., and K. E. Newman. 1987. Effects of yeast culture supplements on the growth and activities of rumen bacteria in continuous culture. J. Anim. Sci. 65 (Suppl. 1): 452 (Abstr.).

Dawson, K.A., K.E. Newman and J.A. Boling, 1990. Effects of microbial supplements containing yeast and lactobacilli on roughage-fed ruminal microbial activities. J. Anim. Sci. 68: 3392.

Duncan, D.B., 1955. Multiple range and multiple F-test Biometerics, 11-1.

Erdman, R. A., and B. K. Sharma. 1989. Effect of yeast culture and sodium bicarbonate on milk yield and composition in dairy cows. J. Dairy Sci. 72:19291932.

Fallon, R.J. and F.J. Harte, 1987. The effect of yeast culture inclusion in the concentrate diet on calf performance. J. Dairy Sci. 70 (Suppl. 1):143 (Abstr.).

Fayed M.A., 1995. Factors affecting productive performance of buffalo male calves till slaughter .Ph.D. Thesis Fac. of A gric . Ain Shams Unv.

Fuller, R. 1989. Probiotics in man and animals. J. Appl. Bacteriol. 66:365.

Gaines,W.L., 1923. Relation between percentage of fat content and yield of milk .1Correction of milk yield for fat content .Agric..Exo. Sta. Bull. 245.

Harris, B., Jr., D.E. Dorminey, W.A. Smith, H.H. Van Horn and C.J. Wilcox, 1992. Effects of feather meal at two protein concentrations and yeast culture on production parameters in lactating dairy cows. J. Dairy Sci. 75:3524.

Harrison, G.A., R. W. Hemken, K.A. Dawson, R.J. Harmon and K.B. Barker, 1988. Influence of addition of yeast culture supplement to diets of lactating cows on ruminal fermentation and microbial populations. J. Dairy Sci. 71:2967-2975.

Ibrahim, F.A., Safaa N. Abdel Azeem, Kh.M.M. Mousa and Hoda M. El Hosseiny, 2006. Impact of using feed additives with corn stover silage in lamb rations on performance, digestibilities, rumen activity, some blood constitutes and carcass traits. J. Agric. Sci. Mansoura Univ. 31 (5):2671.

Judkins, M.B. and R.H. Stobart, 1988. Influence of two levels of enzyme preparation on ruminal fermentation, particulate and fluid passage, and cell wall digestion in wether lambs consuming either a $10 \%$ or $25 \%$ grain diet. J. Anim. Sci. 66: 1010.

Kellems, R.O., A. Lagerstedt, and M.V. Wallentine, 1990. Effect of feeding Aspergillus oryzae fermentation extract or Aspergillus oryzae plus yeast culture plus mineral and vitamin supplement on performance of Holstein cows during a complete lactation. J. Dairy Sci. 73:2922-2928.

Kim, D.Y., D.P. Dawson, B.A. Kent, M.J. Arambel and B.J. Hardcastle, 1993. Effects of supplemental viable yeast culture with or without Aspergillus oryzae on body weight gain and nutrient digestibility in Holstein heifers. J. Dairy Sci. 76 (Suppl. 1):222 (Abstr.).

Lewis,D; Hill, K.J. and Annison, E.F., 1957. Blood-Urea concentration in relation to protein utilization in the ruminant .J.Agric.ASci.48,438-446.

Ling, E.R., 1963. A Text Book of Dairy Chemistry Vol. 2, $3^{\text {rd }}$ Ed. Chapman and Hall Ltd, London.

Malcolm, K.J. and H.E. Kiesling, 1986. Influence of live yeast culture and whole cottonseed on milk production and butterfat production of lactating dairy cows and rumen fermentation of steers. J. Anim. Sci. 63 (Suppl. 1):473. (Abstr.) 
Martin, S. A., and D. J. Nisbet. 1990. Effects of Aspergillus oryzae fermentation extract on fermentation of amino acids, bermudagrass, and starch by mixed ruminal microorganisms in vitro. J. Anim. Sci. 68:2142.

Mohi-Eldin, A. M. A.; Fatheia A. Ibrahim and E. E. Ragheb, 2008. Effect of using natural feed additives on feed utilization and growth performance of growing Friesian male calves. Egyptian J. Nutrition and feds 11(1):159.

Nisbet, D. J. and S. A. Martin, 1991. Effect of a Saccharomyces cerevisiae culture on lactate utilization by the ruminal bacterium Selenomonas ruminantium. J. Anim. Sci. 69:4628.

NRC, 1989. Nutrient Requirements of Dairy Cattle $6^{\text {th }}$ Rev. Ed. $1^{\text {st }}$ printing. Natunal Research Council, Acad. Sci. Washington, D.C.

Piva, G., S. Belladonna, G. Fusconi, and F. Sicbaldi, 1993. Effects of yeast on dairy cow performance, ruminal fermentation, blood components, and milk manufacturing properties. J. Dairy Sci. 76:2717-2722.

Quinonez, J.A., L.J. Bush, T. Nalsen, and G. D. Adams, 1988. Effect of yeast culture on intake and production of dairy cows fed high wheat rations. J. Dairy Sci. 71 (Suppl. 1):275.(Abstr.)

Reddy, C.N., M.R. Reddy and G.V.N. Reddy, 1989. Ammoniation of sorghum straw with urea /anhydrous ammonia for improved utilization among crossbred catle.Indian.J.Anim.Sci.59:986.

SAS, 1996. Statistical Analysis SAS User's Guide: Statistics SAS Institute Inc. Ed. Cary, NC.

Smith, N.E., I.S. Cotlar, D.L.Btlh, W.L. Dunkley and A.A. Franke, 1980. Whole cotton seed and extruded soybean for cows in early lactation. J. Anim. Sci, 53(2): 217-226.

Soder, K.J. and Holden, L.A., 1999. Dry matter intake and milk yield and composition of cows fed yeast prepartum and postpartum. J. Dairy Sci. 82:605.

Swartz, D. L., L. D. Muller, G. W. Rogers, and G. A. Varga. 1994. Effect of yeast cultures on performance of lactating dairy cows: a field study. J. Dairy Sci. 77:3073.

Van Keulen, J. and B.A. Young, 1977. Evalution of acid insoluble ash as a natural marker in ruminant digestibility studies . J.Anim.Sci.,44;282.

Warner, A.C.I., 1964. Production of volatile fatty acids in the rumen methods of measurements. Nutr. Abst. Rev., 34:339.

Wiedmeier, R. D., M. J. Arambel, and J. L. Walters, 1987. Effects of yeast culture and Aspergillus oryzae fermentation extract on ruminal characteristics and nutrient digestibility. J. Dairy Sci. 70:2063-2068.

Williams, P.E.V., C.A.G. Tait, G. M. Innes, and C. J. Newbold, 1991. Effects of the inclusion of yeast culture ( Saccharomyces cerevisiae plus growth medium) in the diet of dairy cows on milk yield and forage degradation and fermentation patterns in the rumen of steers. J. Anim. Sci. 69:3016-3026.

Wohlt, J. E., A.D. Finkelstein, and C.H. Chung, 1991. Yeast culture to improve intake, nutrient digestibility, and performance by dairy cattle during early lactation. J. Dairy Sci. 74: 1395-1400.

Wohtlt, J.E, T.T. Corcione and P.K. Zajac, 1998. Effect of yeast on feed intake and performance of cows fed diets based on corn silage during early lactation. J. Dairy Sci., 81:1345. 


\section{تأثير إستخدام الإضافات الطبيعية على الآداء الإنتاجى للأبقار الفريزيان الحلابة}

عبد المنعم محمد مصطفى زيلد، عبد الحليم محمد عبد السلام محى الدين، إبراهيم محمد السيد شقوير، ابتهاج ابراهيم محمد أبو العنين، فتحية عبد العظيم إبراهيم مليد

\section{معهز بحوث الإنتاج الحيوانى، مركز البحوث الزراعية، وزارة الزراعة، جمهورية مصر العربية}

أجريت الدراسة بإستخدام ب بقرة فريزيان حلاب متوسط أوزانها الحى .0r كجم وذلك ل لدراسة تأثير

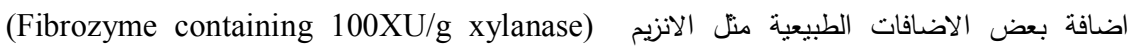
والخميرة,وبea-Sacc containing $10^{8}$ cells of Saccharomyces cerevesiae/g) على كفاءة النتاج

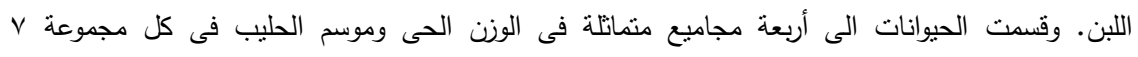

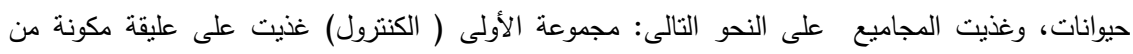

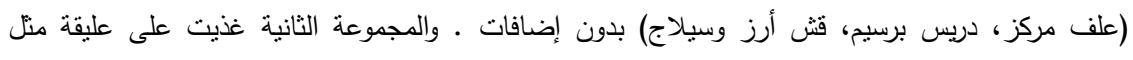

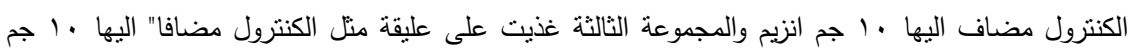

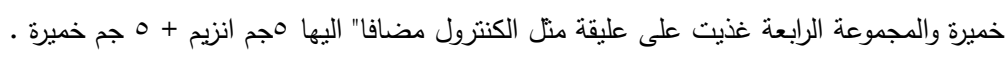

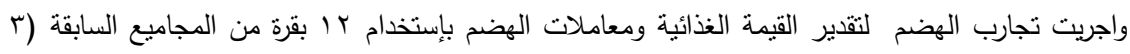

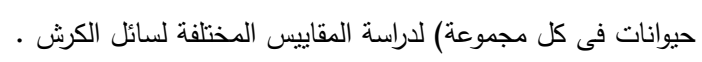

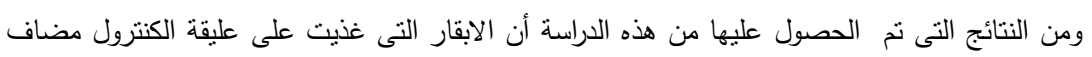

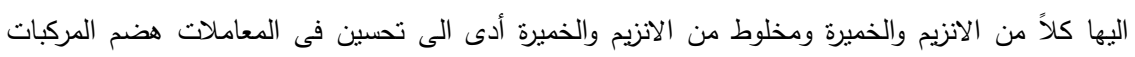

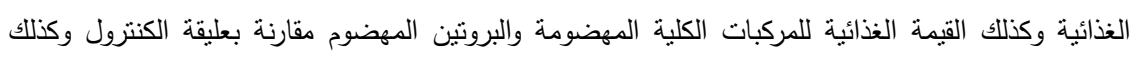

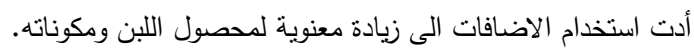

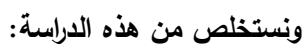
أن استخدام الخميرة منفردة أو مخلوط مع الانزيم (بنسبة ه جم لكل منها) أدت إلى تحسين معاملات الهضم والقيمة الغذائية وYنتاج اللبن الأبقار الحلابة. 